\title{
Evaluation of Skin Protective Effect Using in Vitro Cell Line Models of Biofield Energy-Consciousness Energy Healing Treated Herbomineral Formula
}

\author{
William Dean Plikerd ${ }^{1}$, Mahendra Kumar Trivedi ${ }^{1}$, Alice Branton ${ }^{1}$, Dahryn Trivedi ${ }^{1}$, \\ Gopal Nayak ${ }^{1}$, Mayank Gangwar ${ }^{2}$, Snehasis Jana ${ }^{2, *}$ \\ ${ }^{1}$ Trivedi Global, Inc., Henderson, NV, USA \\ ${ }^{2}$ Trivedi Science Research Laboratory Pvt. Ltd., Bhopal, Madhya Pradesh, India
}

Email address:

publication@trivedisrl.com (S. Jana)

*Corresponding author

\section{To cite this article:}

William Dean Plikerd, Mahendra Kumar Trivedi, Alice Branton, Dahryn Trivedi, Gopal Nayak, Mayank Gangwar, Snehasis Jana. Evaluation of Skin Protective Effect Using in Vitro Cell Line Models of Biofield Energy-Consciousness Energy Healing Treated Herbomineral Formula. American Journal of Health Research. Vol. 5, No. 3, 2017, pp. 65-75. doi: 10.11648/j.ajhr.20170503.13

Received: March 28, 2017; Accepted: April 10, 2017; Published: May 9, 2017

\begin{abstract}
Alternative or natural systems of medicine are practiced worldwide that mostly emphasize research of herbal formulations, which might be helpful against various disorders. The objective of this study was to evaluate the influence of The Trivedi Effect ${ }^{\mathbb{B}}$-Consciousness Energy Healing Treatment on an herbomineral test formulation and cell medium (DMEM) for the skin health. The formulation contained minerals (zinc chloride, sodium selenate, and sodium molybdate), L-ascorbic acid, herbal (Centella asiatica) extract, and tetrahydrocurcumin (THC). The test formulation and DMEM media were divided into two equal parts. One part received Biofield Energy Treatment (BT) by William Dean Plikerd and other part was denoted as the untreated test items (UT). MTT assay showed that the test formulation was found safe and nontoxic with greater than $75 \%$ cell viability against various tested concentrations. The cell proliferation using BrdU method showed improved cell proliferation by $43.63 \%$ and $10.97 \%$ in the BT-DMEM + UT-Test formulation and BT-DMEM + BT-Test formulation group, respectively at $17.5 \mu \mathrm{g} / \mathrm{mL}$ compared with the untreated group. The collagen level was significantly increased by $2.65 \%$ and $23.56 \%$ at 2.5 and $1.25 \mu \mathrm{g} / \mathrm{mL}$, respectively in the UT-DMEM + BT-Test formulation compared with the untreated group. The elastin level was increased by $8.34 \%$ at a concentrations of $2.5 \mu \mathrm{g} / \mathrm{mL}$ in the BT-DMEM + BT-Test formulation group compared with the untreated group. However, the hyaluronic acid (HA) level was increased by $2.60 \%$ at $0.625 \mu \mathrm{g} / \mathrm{mL}$ in the BT-DMEM + UTTest formulation group compared with the untreated group. Moreover, melanin synthesis was decreased by $14.22 \%$ and $17.61 \%$ in the UT-DMEM + BT-Test formulation and BT-DMEM + UT-Test formulation groups, respectively at a concentration of $0.125 \mu \mathrm{g} / \mathrm{mL}$. Anti-wrinkling activity in HFF-1 cells showed improve cell viability by $14.54 \%$ and $11.32 \%$ at $1.25 \mu \mathrm{g} / \mathrm{mL}$ in the UT-DMEM + BT-Test formulation and BT-DMEM + BT-Test formulation groups, respectively compared with the untreated group. Wound healing scratch assay results showed significantly increased healing rates by $10.5 \%$ and $8.3 \%$ in the HFF-1 and HaCaT cells lines, respectively in the Biofield Energy Healing based test formulation. In conclusion, The Trivedi Effect ${ }^{\circledR}$ based test formulation and DMEM could be useful to improve the skin ECM components, along with protection against UV-B rays, which could be useful for the development of an effective cosmetic product for the prevention and treatment of several skin problems such as erythema, contact dermatitis, skin aging, wrinkles and/or change in the skin color, etc. as an anti-ageing, skin-whitening, and anti-wrinkling.
\end{abstract}

Keywords: Consciousness Energy Healing Treatment, B16-F10, HaCaT, HFF-1, Hyaluronic Acid, Scratch Assay, Tetrahydrocurcumin 


\section{Introduction}

According to World Health Organization (WHO), today's medicinal therapies are mostly based on traditional (wholistic or alternative) medicine not the western allopathic model, which showed significant therapeutic outcome in every continent of the globe. For a healthy life, most of the population are now using traditional approach instead of synthetic drugs, such as natural and organic foods, herbal medicines, naturopathic treatments, and many more [1]. The herbal based medicines and formulations are defined as the oldest form of healthcare treatment known to mankind, which has now been more developed with extensive discovery and observations. Herbal based cosmetics products are highly chosen due to lower incidences of adverse effect compared with synthetic cosmetics [2-4]. However, the side effects of synthetic cosmetics and skin health products may lead to serious health complications [5]. It can be established that the new cosmetic market is driven towards herbal drugs, herbal cosmetics, nutraceuticals, and natural dyes. Most of the natural medicines are wide spread and many plant based metabolites are used by pharmaceutical industries for the development of novel formulations. With the continued interest of herbal based products in cosmetology, a new herbomineral formulation was formulated to maintain overall skin health. The composition of test formulation included minerals (such as zinc chloride, sodium selenate, and sodium molybdate), L-ascorbic acid, tetrahydrocurcumin (THC), and plant extract of Centella asiatica (commonly known as Jal Brahmi). Zinc, copper, and selenium are very commonly used in cosmetic products due to their wide range of application in skin health. The selected minerals have been reported with strong antimicrobial, antioxidant, and free radical scavenging effects with improved skin synthesis of extra cellular components [6,7]. Furthermore, L-ascorbic acid (Vitamin C) and some other vitamins play an important role in skin health, anti-wrinkling, and significant wound healing action [8]. In addition, THC is one of the major active metabolites of curcumin [9] that has a strong antioxidant property $[10,11]$. The plant extract used in the test formulation is $C$. asiatica, which has a reported application in skin ageing, and wound healing action. Besides, C. asiatica extract based cosmetics products have been used in many products [12].

Conventional biomedicine has expanded in healthcare as multiple therapeutic approaches. Numerous Complementary and Alternative Medicine (CAM) therapies have been practiced worldwide with minimally invasive procedures in order to improve the endogenous energy flows. The term Biofield is a unifying concept and act as a bridge between traditional and contemporary models of energy medicine [13]. The Biofield Energy Treatment has been reported with significant results in both clinical practice and scientific research, which focus on energy fields of the body. Biofield is defined as a massless field, not necessarily the electromagnetic, which surrounds and permeates the living bodies and affects the body [14]. Various diverse modes of energetic healing were reported and defined under Biofield Energy Therapies, which were also accepted by the NIH (National Institute of Health). Biofield Energy Healing (The Trivedi Effect $^{\mathbb{B}}$ ) has been described worldwide with remarkable results in nonliving materials and in living organisms. The Trivedi Effect $^{\circledR}$ has been found with momentous results in the field of microbiology [15-17], agriculture science $[18,19]$, livestock [20], and materials science [21-24]. With this diversifying results and application of Biofield Energy Healing, a new Biofield Energy Healing based herbomineral formulation was designed for skin health, which was tested in cell lines such as HFF-1, HaCaT, and B16-F10 cell lines.

\section{Materials and Methods}

\subsection{Chemicals and Reagents}

The test formulation consisted of components such as zinc chloride, which was purchased from TCI, Japan, sodium selenate from Alfa-Aesar, USA, while sodium molybdate from Sigma-Aldrich. Tetrahydrocurcumin and Centella asiatica extract were procured from Novel Nutrients Pvt. Ltd., India and Sanat Products Ltd., India, respectively. Lascorbic acid as a positive control was purchased from AlfaAesar, while kojic acid and 3-(4, 5-diamethyl-2-thiazolyl) 2, 5 diphenyl-2 $H$-tetrazolium) (MTT) were purchased from Sigma Chemical Co. (St. Louis, MO). Epidermal growth factor (EGF) was procured from Gibco, ThermoFisher, USA. ELISA kits for the estimation of extracellular matrix component were procured from CUSABIO and CusAb Co. Pvt. Ltd, USA. Fetal bovine serum (FBS) and DMEM were purchased from Gibco, USA. Antibiotics solution (PenicillinStreptomycin) were procured from HiMedia, India, while Direct Red 80 and EDTA were purchased from Sigma, USA. All the other chemicals used in this experiment were analytical grade procured from local vendors.

\subsection{Cell Culture}

Three cell lines were used for the estimation of skin health parameters. HFF-1 (human foreskin fibroblast) cells were procured from American Type Culture Collection (ATCC), USA, originated from normal human skin fibroblast cells. B16-F10 (mouse melanoma) and $\mathrm{HaCaT}$ (human keratinocytes) cells were procured from National Centre for Cell Science (NCCS), Pune, India. HFF-1, HaCaT, and B16F10 cell lines were maintained in the growth medium DMEM supplemented with $15 \%$ FBS, with added antibiotics penicillin $(100 \mathrm{U} / \mathrm{mL})$ and streptomycin $(100 \mu \mathrm{g} / \mathrm{mL})$. The growth condition of cell lines were $37^{\circ} \mathrm{C}, 5 \% \mathrm{CO}_{2}$, and $95 \%$ humidity. L-ascorbic acid (for ECM, UV-B protection, and wound healing assay) at the concentrations ranges from 10 $\mu \mathrm{M}$ to $1000 \mu \mathrm{M}$, while kojic acid (for melanin) concentrations ranges from $1 \mathrm{mM}$ to $10 \mathrm{mM}$. FBS $(0.5 \%)$ was used in cell proliferation assay in BrdU assay, while 
EGF $10 \mu \mathrm{M}$ used in non-cytotoxic dose concentration in MTT assay.

\subsection{Experimental Design}

The experimental groups consisted of cells in normal control group, vehicle control group (0.05\% DMSO), positive control group (L-ascorbic acid/kojic acid/EGF/FBS) and experimental tested groups, which included the combination of Biofield Energy Treated and untreated test formulation/DMEM. It consisted of four major treatment groups on specified cells with UT-DMEM + UT-Test formulation, UT-DMEM + Biofield Treated Test formulation (BT-Test formulation), BT-DMEM + UT-Test formulation, and BT-DMEM + BT-Test formulation.

\subsection{Energy of Consciousness Treatment Strategies}

The test formulation and DMEM were divided into two parts for Biofield Treatment. One part of the test formulation was treated with the Biofield Energy by a renowned Biofield Energy Healer (also known as The Trivedi Effect ${ }^{\mathbb{R}}$ ) and coded as the Biofield Energy Treated formulation and DMEM, while the second part of the test samples did not receive any sort of treatment and was defined as the untreated test samples. William Dean Plikerd, a renowned Biofield Energy Healer performed the Biofield Energy Treatment to the test formulation and DMEM for 5 minutes through the Healer's unique Energy Transmission process, which was done remotely from USA. However, the test samples were located in India (Laboratory of Dabur Research Foundation, near New Delhi, India). The Biofield Energy Healer, William Dean Plikerd, never visited the laboratory, nor had any contact with the test samples. Further, for comparison purpose, control test samples were treated by sham healer. The sham healer did not have any knowledge about the Biofield Energy Treatment. After that, the Biofield Energy Treated and untreated samples were kept in similar sealed conditions for study.

\subsection{Determination of Non-cytotoxic Concentrations}

The cell proliferation in cell lines such as HFF-1, HaCaT, and B16-F10 were performed by MTT assay. The cells counted and plated in 96 well plates at the density corresponding to $5 \times 10^{3}$ to $10 \times 10^{3}$ cells $/$ well $/ 180 \mu \mathrm{L}$ of cell growth medium. The cells were incubated overnight under specific growth conditions that allowed the cell recovery and exponential growth, which were subjected to serum stripping or starvation. The cells were subsequently treated to the Biofield Energy Treated and untreated groups of test formulation/DMEM at a range of concentrations ( 0.008 to 10 $\mu \mathrm{g} / \mathrm{mL})$ and ascorbic acid $(10$ and $50 \mu \mathrm{M})$ followed by incubation from 24 to 72 hours in $\mathrm{CO}_{2}$ incubator at $37^{\circ} \mathrm{C}, 5 \%$ $\mathrm{CO}_{2}$ and $95 \%$ humidity. Further, serum free MTT media (20 $\mu \mathrm{L}$ of $5 \mathrm{mg} / \mathrm{mL}$ ) was added to each well followed by incubation for 3 hours at $37^{\circ} \mathrm{C}$. The supernatant was aspirated and $150 \mu \mathrm{L}$ of DMSO was added to each well to dissolve the formazan crystals. Thereafter, the absorbance of each well was recorded at $540 \mathrm{~nm}$ using Synergy HT micro plate reader, BioTek, USA. The concentrations that exhibited percentage cytotoxicity of less than $30 \%$ was considered as non-cytotoxic [25].

\subsection{Effect of Test Formulation on Human Foreskin Fibroblast (HFF-1) Cell Proliferation Using BrdU Method}

Fibroblast cell proliferation assay was done using BrdU method with HFF-1 cells, which were counted using hemocytometer and plated in 96 well plate at the density corresponding to $1 \times 10^{3}$ to $5 \times 10^{3}$ cells/well in DMEM supplemented with $15 \%$ FBS. The cells were then incubated overnight under growth conditions so as to allow cell recovery and exponential growth. Following overnight incubation, the above cells were subjected to serum starvation. Following serum starvation, the cells were treated with non-cytotoxic concentrations of test formulation in different defined experimental groups and positive control. Following 24 to 72 hours of incubation with the test substance and positive control, the plates were taken out and BrdU (5-bromo-2'-deoxyuridine) estimated using Cell Proliferation ELISA, BrdU estimation kit (ROCHE 11647229001 ) as per manufacturer's instructions.

\subsection{Estimation of Extracellular Matrix Component (ECM) Synthesis}

Synthesis of extracellular matrix components (i.e. collagen, elastin and hyaluronic acid) in HFF-1 cell line was estimated for determining the potential of the test formulation to improve skin strength, overall elastin, and hydration level. HFF-1 cells were counted using hemocytometer and plated in 48 well plate at the density corresponding to $10 \times 10^{3}$ cells/well in DMEM supplemented with $15 \%$ FBS. The cells were then incubated overnight under specified growth conditions followed by cells to serum stripping. Further, the cells were treated with the test item treatment at different experimental combination groups with DMEM group viz. vehicle control (DMSO, 0.05\%), and positive control (ascorbic acid, at $10 \mu \mathrm{M}$ ). Further, 72 hours of incubation with the test items and positive control, the supernatants from all the cell plates were taken out and collected in pre labeled centrifuge tubes for the estimation of elastin and hyaluronic acid levels. However, the corresponding cell layers were processed for the estimation of collagen levels using Direct Sirius red dye binding assay. Elastin and hyaluronic acid were estimated using ELISA kits from Cusabio Biotech Co. Ltd, Human Elastin ELN Elisa kit 96T and Human Hyaluronic Acid Elisa kit 96T, respectively [26].

\subsection{Estimation of Melanin Synthesis- Skin Depigmentation Effect}

B16-F10 cells were used for melanin synthesis estimation, cells were counted using hemocytometer and plated in 90 $\mathrm{mm}$ culture dish at the density corresponding to $2 \times 10^{6} / 6 \mathrm{~mL}$ in culture plates. Further, the cells were incubated overnight 
under specified growth conditions and allowed for cell recovery and exponential growth. After incubation, the cells were treated with $\alpha$-melanocyte-stimulating hormone ( $\alpha$ $\mathrm{MSH}$ ) for a time point ranging from 4 to 24 hours for stimulation of intracellular melanin synthesis. Further, the cells were incubated with $\alpha-\mathrm{MSH}$, and then treated with concentration at $0.625,1.25$ and $2.5 \mu \mathrm{g} / \mathrm{mL}$ of test formulation with DMEM for a time period from 48 to 96 hours. After incubation, intracellular melanin was extracted in $\mathrm{NaOH}$ and the absorbance was recorded at $405 \mathrm{~nm}$. The level of melanin was extrapolated using standard curve obtained from purified melanin [27].

\subsection{Anti-Wrinkling Effects of Test Formulation on HFF-1 Cells Against $U V-B$ Induced Stress}

UV-B induced stress was evaluated in HFF-1 cells and cell viability was estimated in the presence of test formulation. The cells were counted using hemocytometer and plated in 96 well plate at the density corresponding to $5 \times 10^{3}$ to $10 \times$ $10^{3}$ cells/well in DMEM supplemented with 15\% FBS cells/plates, which were incubated overnight under growth conditions to allow cell recovery and exponential growth. The cells were treated with non-cytotoxic concentrations of test formulation for 2 to 24 hours. After treatment, the cells were subjected to lethal dose of UV-B irradiation (200 $\mathrm{mJ} / \mathrm{cm}^{2}$ ) that can lead to approximately $50 \%$ cytotoxicity (302 nm, CL-1000 M, UVP, USA) [28]. The percent cell viability was assessed using formula (1)-

$$
\% \text { Cell viability }=\left(\mathrm{X}^{*} 100\right) / \mathrm{R}
$$

Where $\mathrm{X}$ represents the absorbance of cells corresponding to positive control and test groups, and $\mathrm{R}$ represents the absorbance of cells corresponding to baseline (control cells) group.

\subsection{Wound Healing Scratch Assay}

HFF-1 and HaCaT cell lines were counted using hemocytometer and plated in 12 well plates at the densities $0.08 \times 10^{6} / \mathrm{well} / \mathrm{mL}$ of cell growth medium. The cells/plates was incubated overnight under growth conditions and allowed cell recovery and exponential growth. After overnight incubation, the cells were subjected to the serum starvation in DMEM for 24 hours. Mechanical scratch wound was created in the near confluent monolayer of cells by gently scrap with the sterile $200 \mu \mathrm{L}$ micropipette tip. The cells were rinsed with serum free DMEM and treated with test formulation. The scratched area was monitored for a time period ranging from 0 to 48 hours for closure of wound area. The photomicrographs were done at the selected time point's for quantitative assessment of migrated cells using digital camera, which was connected to the inverted microscope. All the observations were calculated and compared with positive and vehicle control [29].

\subsection{Statistical Analysis}

Each experiment was carried out in three independent assays and was represented as mean values with standard error of mean (SEM). Student's $t$-test was used to compare two groups to judge the statistical significance. For multiple group comparison, one-way analysis of variance (ANOVA) was used followed by post-hoc analysis using Dunnett's test. Statistically significant values were set at the level of $p \leq 0.05$.

\section{Results and Discussions}

\subsection{Non-cytotoxic Effect of Test Formulation on Cell Lines}

The cytotoxic effect of the test formulation was tested on all the three cell lines i.e. HFF-1, HaCaT and B16-F10. The results were compared with respect to ascorbic acid $(10 \mu \mathrm{M})$ and EGF $(10 \mathrm{ng} / \mathrm{mL})$ at defined concentrations for estimation of percentage cell viability. The results are presented in Figure 1, with more than $75 \%$ in all the cell lines at different concentrations and found safe up to maximum of $40 \mu \mathrm{g} / \mathrm{mL}$ against the tested cell lines. Hence, these tested concentrations were selected for further estimation of cellular proliferation using BrdU assay, identification of extracellular matrix (ECM) synthesis (e.g. collage, elastin, and hyaluronic acid), melanin and wound healing scratch assay in various cell lines.
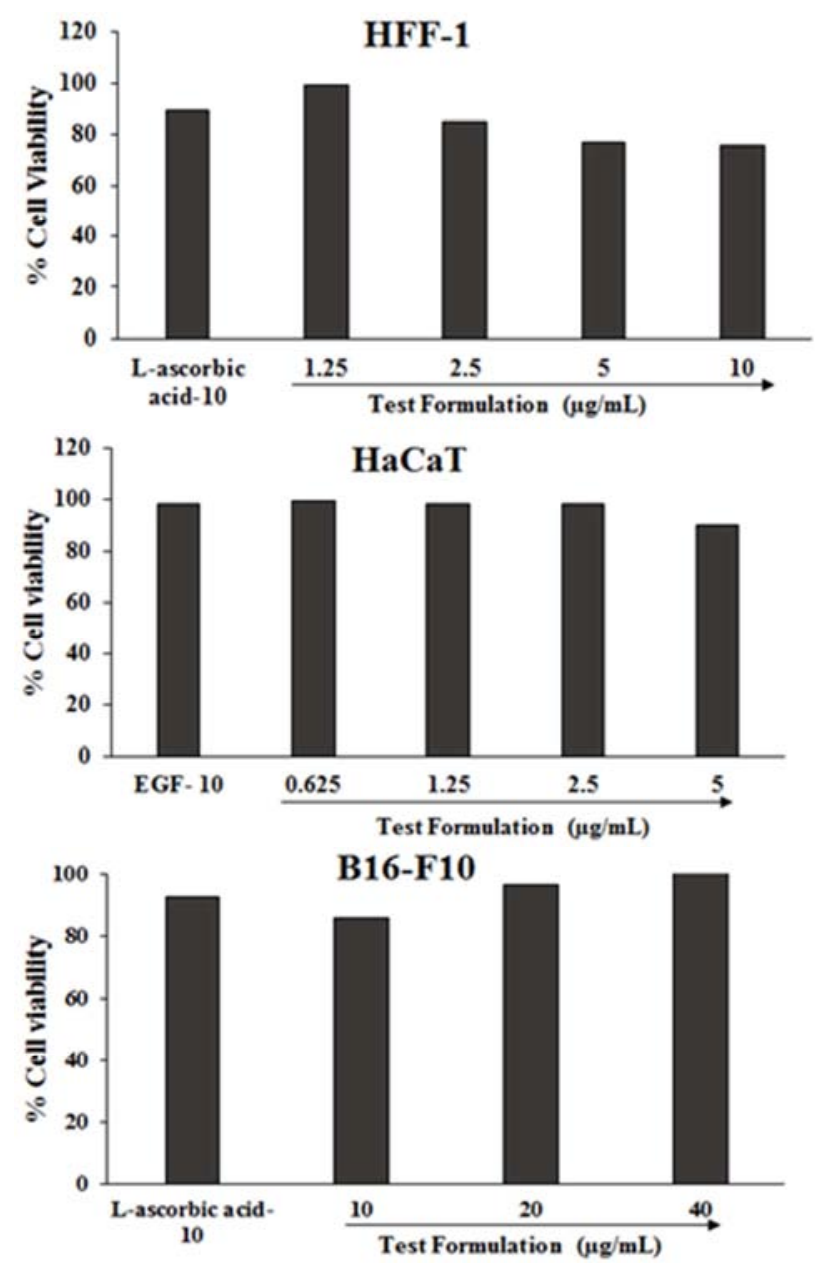

Figure 1. Effect of the herbomineral formulation on HFF-1, HaCaT, and B16-F10 cell lines for cell viability using the MTT assays. EGF-10: Epidermal growth factor $(10 \mu \mathrm{M})$. 


\subsection{Effect of the Biofield Energy Treated Test Formulation on Human Foreskin Fibroblast Cell Proliferation (BrdU Method)}

The results of percentage cellular proliferation using BrdU assay at different concentrations of Biofield Treated and untreated test formulation with DMEM in HFF-1 cells after 48 hours of incubation are represented in Figure 2. FBS at concentration of $0.5 \%$ showed significant increased proliferation rate to $250.4 \%$. This suggests that FBS significantly improved the proliferation rate by $150 \%$ and $133 \%$ compared with normal and vehicle control group respectively. The Biofield Treated groups, such as BTDMEM + UT-Test formulation and BT-DMEM + BT-Test formulation showed significant increased cellular proliferation at $17.5 \mu \mathrm{g} / \mathrm{mL}$ by $43.63 \%$ and $10.97 \%$, respectively compared with the UT-DMEM + UT-Test formulation group. In addition, UT-DMEM + BT-Test formulation and BT-DMEM + UT-Test formulation showed significant increased cellular proliferation at $8.75 \mu \mathrm{g} / \mathrm{mL}$ by $26.98 \%$ and $32.67 \%$, respectively compared with the UTDMEM + UT-Test formulation group. However, the test formulation per se showed significantly improved proliferation rate at all the tested concentrations compared with the normal and vehicle control group. These data suggests that the Biofield Energy Treated test formulation results in significant increase in cellular proliferation in $\mathrm{HFF}-$ 1 cells at $17.15 \mu \mathrm{g} / \mathrm{mL}$ using BrdU assay.

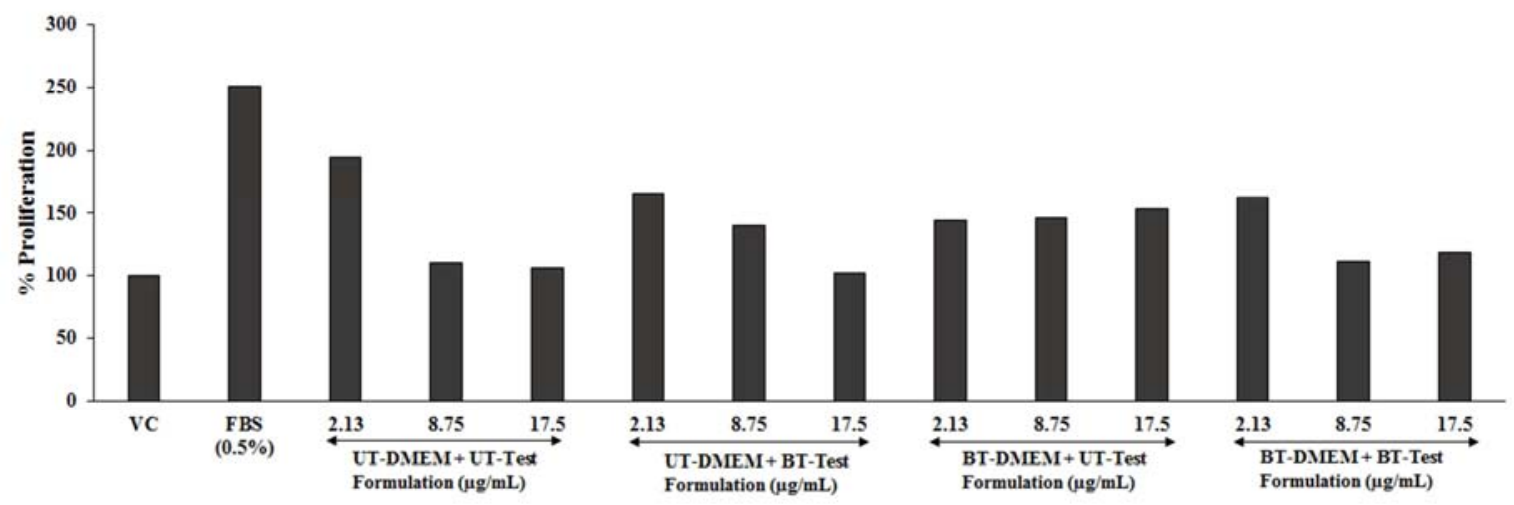

Figure 2. Effect of the Biofield Energy Treated Test formulation with DMEM on cellular proliferation in HFF-1 cells after 48 hours. VC: Vehicle control; FBS: Fetal bovine serum; UT: Untreated; BT: Biofield Treated.

\subsection{Analysis of Extracellular Matrix Component Synthesis}

The extra cellular matrix components (ECM) were assessed in order to identify the skin strength, hydration level and overall elasticity using Biofield Energy Treated test formulation/DMEM in HFF-1 cell line. The results of the study are presented as collagen, elastin and hyaluronic acid levels.

\subsubsection{Collagen Analysis}

The effect of the Biofield Energy Treated Test formulation/DMEM on collagen level in HFF-1 cell line showed significant increase in the collagen concentrations. Collagen is considered as one of the most abundant proteins, responsible for skin health, structure and most abundant fibrous protein present in ECM. Experimental results of collagen with respect to ascorbic acid and Biofield Energy Treated Test formulation/DMEM groups are presented in Figure 3. Ascorbic acid $(10 \mu \mathrm{M})$ showed significant increased collagen content by $55 \%$, while the Biofield Energy Treated Test formulation at concentration range from 0.625 to $2.5 \mu \mathrm{g} / \mathrm{mL}$ reported with the significant alteration of collagen amount.

The Biofield Energy Treated group, UT-DMEM + BT-Test formulation reported with a significant increase in collagen level at 2.5 and $1.25 \mu \mathrm{g} / \mathrm{mL}$ by $2.65 \%$ and $23.56 \%$, respectively compared to the UT-DMEM + UT-Test formulation group. Similarly, in BT-DMEM + UT-Test formulation group at $1.25 \mu \mathrm{g} / \mathrm{mL}$ showed an increased collagen level by $13.36 \%$, compared with the UT-DMEM + UT-Test formulation group. Therefore, it can be assumed that Biofield Energy Treatment has the ability to increase the collagen level at tested concentrations. Hence, it can be assumed that the procollagen peptides and cross-linking (aldol reaction) among various tropocollagen molecules were increased after Biofield Energy Treatment, which results in improved collagen fibrils. Collagen fibrils are essential to provide strength and structure to the skin [30,31]. These study data suggests the potential of The Trivedi Effect ${ }^{\circledR}$ showed a remarkable increase in the collagen level, which could be beneficial for skin health, strength, and structure and wound healing. 


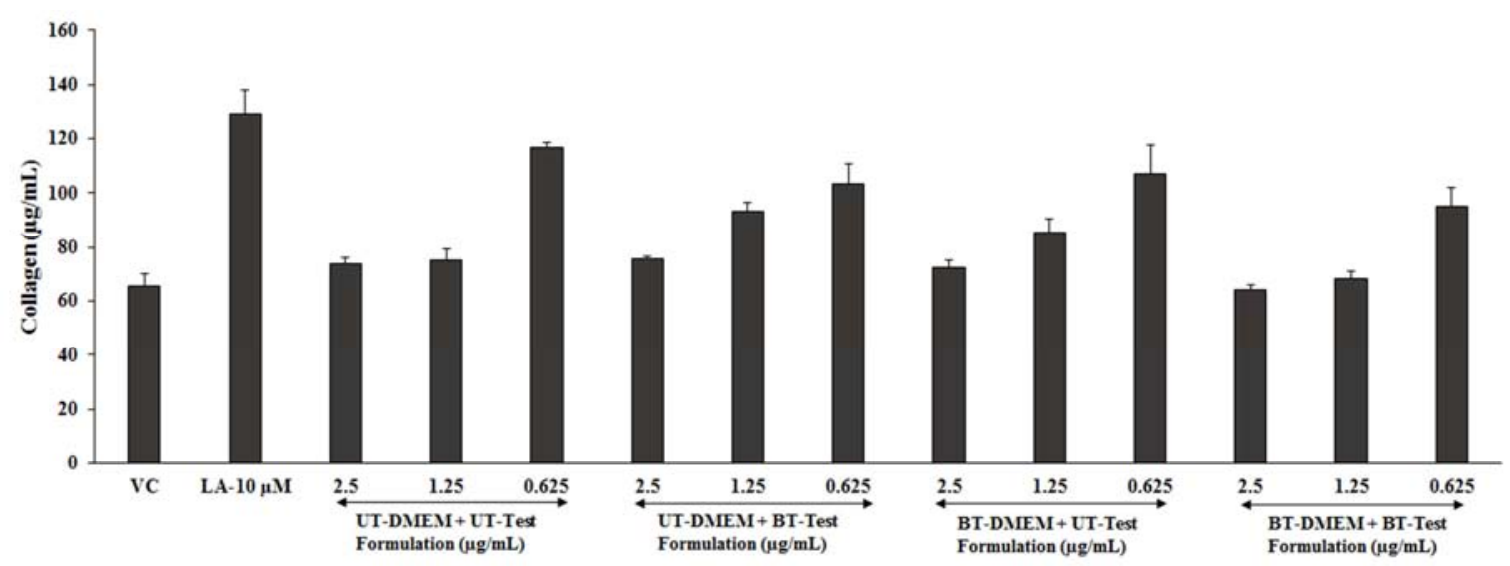

Figure 3. Effect of the Biofield Energy Treated Test formulation with DMEM on human dermal fibroblast (HFF-1) cell line for collagen level. VC: Vehicle control; LA-10: L-Ascorbic acid at $10 \mu M$ concentration; UT: Untreated; BT: Biofield treated.

\subsubsection{Assessment of Elastin}

The Biofield Energy Healing based herbomineral formulation test formulation was evaluated to detect the change in elastin level. Elastin is another important constituent of the ECM, it forms tight junction with collagen fibrils, which helps to maintain the cellular integrity [32]. However, it helps to retain shape in body tissue and very elastic tissue of the body. The results of elastin level in HFF1 cell line due to the Biofield Energy Healing test formulation are shown in Figure 4. Ascorbic acid $(50 \mu \mathrm{M})$ group showed significant increase elastin content $(9.07 \pm$ 0.49 ) by $55 \%$ compared with the normal control group (5.84 \pm 0.64). Among tested groups, BT-DMEM + BT-Test formulation group showed a highly significant increased elastin level by $8.34 \%$ at a concentrations of $2.5 \mu \mathrm{g} / \mathrm{mL}$ compared with the UT-DMEM + UT-Test formulation group. However, various other tested concentrations groups were also reported with altered elastin level after treatment with the Biofield Energy Treated Test formulation compared with the untreated groups. Fibroblast and elastin are responsible for ageing and health, however in ageing the Biofield Energy Healing based Test formulation might be significantly used. The result suggests that an increased elastin level might increase the skin elasticity and strength that activates the dermal metabolism. Therefore, the Biofield Energy Healing based Test formulation and DMEM can be significantly used to improve the elastin level that helps to improve cell growth, survival, differentiation and morphogenesis.

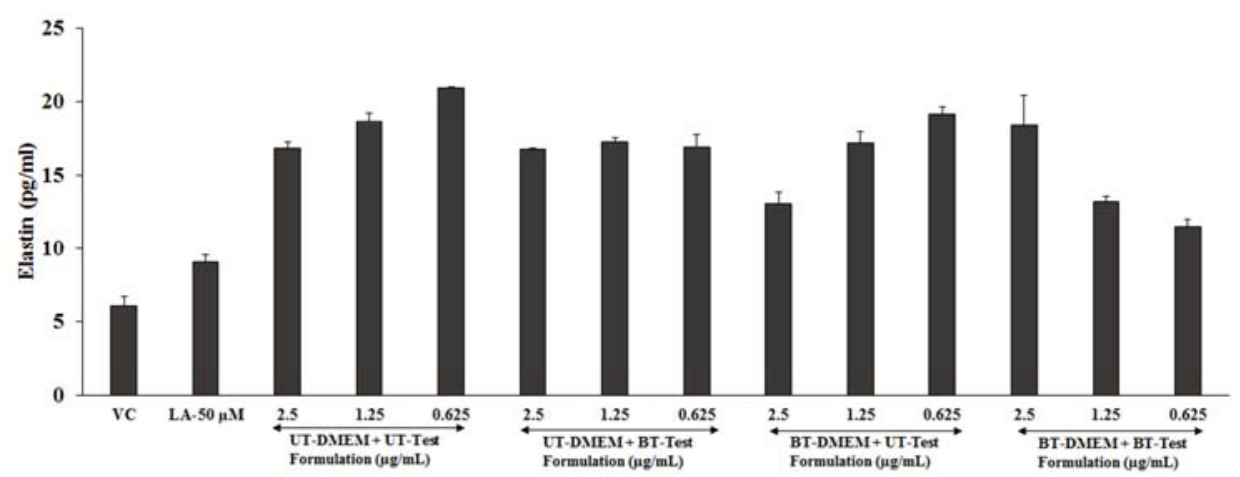

Figure 4. Concentration-dependent effect of Biofield Energy Treated Test formulation on HFF-1 cell line for estimation of elastin. VC: Vehicle control; LA-50: L-Ascorbic acid at $50 \mu M$ concentration; UT: Untreated; BT: Biofield Treated.

\subsubsection{Analysis of Hyaluronic Acid}

The results of hyaluronic acid levels after treatment with the Biofield Energy Healing based test formulation was evaluated in the HFF-1 cell line and are presented in Figure 5. Ascorbic acid group showed a significant increased hyaluronic acid content by $183.6 \%$. Test formulation/DMEM group showed a significant change in HA levels at all the tested concentrations in all the groups with respect to normal control group. However, Biofield Energy Treated BT-DMEM + UT-Test formulation group, showed increased HA level by $2.60 \%$ at $0.625 \mu \mathrm{g} / \mathrm{mL}$ with respect to the UT-DMEM + UT-
Test formulation. The rest of the groups all showed significant change in HA levels, thus the Biofield Energy Healing based Test formulation and DMEM might be a new approach in cosmetology for skin health. HA is a natural polysaccharide and distributed extensively all over the connective, neural, and epithelial tissue. HA helps to retain skin moisture, secures skin moisture, creates fullness, and regulates the skin water balance. In cosmetic market, most of the skin care products uses HA as the base for skin health. Some common marketed skin products such as hyaluronic acid creams, serums, injectable, and hyaluronic acid 
supplements are used to improve the level of HA. It was found that low level of HA might lead to reduced skin elasticity and expose the signs of aging. Overall, on the basis of unique properties of HA in skin health, it was considered as "smart nutrient" because of its moisture holding property. HA based skin car product are widely available in market for skin health [33], but they may have several side effects. However, the Biofield Energy Healing (The Trivedi Effect ${ }^{\circledR}$ ) based Test formulation and DMEM could be an alternative method to improve the level of HA and improve the skin health.

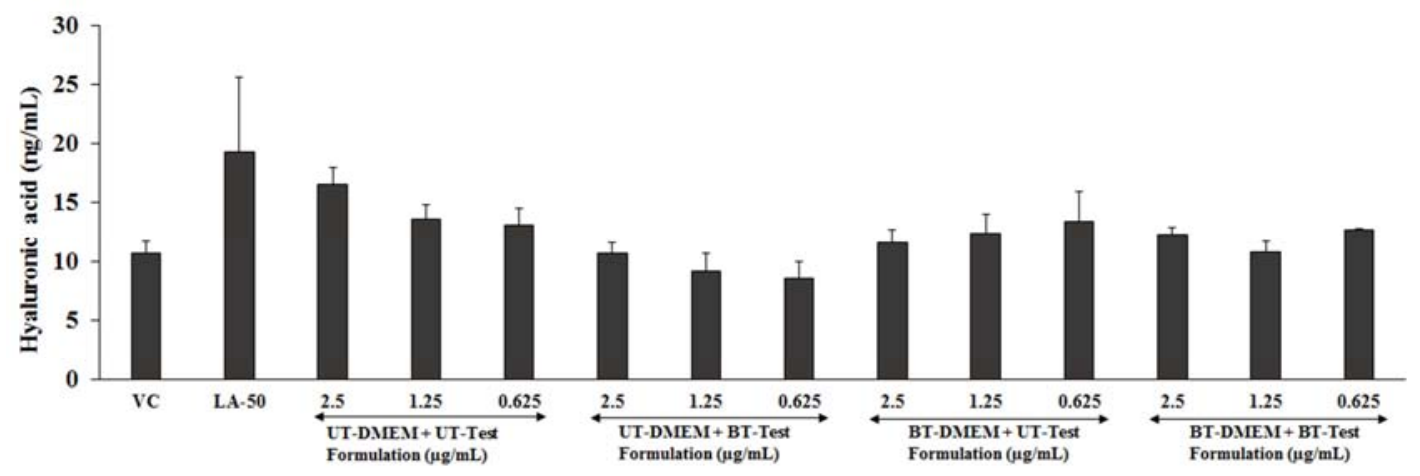

Figure 5. Effects on hyaluronic acid synthesis by Biofield Energy Treated Test formulation in HFF-1 cell lines. VC: Vehicle control; LA-50: L-Ascorbic acid at $50 \mu M$ concentration UT: Untreated; BT: Biofield Treated.

\subsection{Estimation of Melanin Synthesis Inhibition}

Skin complexion and pigmentation are influenced by many factors such as genes, nutrition, and environmental factors, which all contribute to the color of skin. Besides, most notable skin component that contributes to skin pigmentation is the pigment known as melanin. Melanin is of three types i.e. eumelanin, pheomelanin, and neuromelanin, and the most common is eumelanin, which is responsible for colors type brown and black. However, skin depigmentation results in many disorders, when ultraviolet radiations (UV-A and UVB) from the sun initiate the process of melanogenesis in the melanocytes and result in skin darkening [34]. The outcomes of the Biofield Energy Healing based test formulation on the melanogenesis mouse melanoma (B16-F10) cell line are presented in Figure 6. The cells were cultured in DMEM supplemented media containing several concentrations of test formulation and kojic acid $(10 \mu \mathrm{M})$ for 48 to 96 hours were evaluated. Kojic acid, a skin whitening compound was used as positive control, which showed a significantly decreased level of melanin synthesis by $65.30 \%$ compared the melanin level presence in the alpha melanocyte stimulating hormone $(\alpha-\mathrm{MSH})$. The Biofield Energy Healing based test formulation showed a significant decrease in melanin synthesis by $6 \%, 1.01 \%$, and $4.62 \%$ at $0.0625 \mu \mathrm{g} / \mathrm{mL}$ in the UT-DMEM + BT-Test formulation, BT-DMEM + UT-Test formulation, and BT-DMEM + BT-Test formulation groups, respectively. However, at $0.125 \mu \mathrm{g} / \mathrm{mL}$, the melanin synthesis was decreased by $14.22 \%$ and $17.61 \%$ in the UT-DMEM + BT-Test formulation and BT-DMEM + UT-Test formulation groups respectively, compared with the UT-DMEM + UTTest formulation group in B16-F10 melanoma cell line. Hence, it can be suggested that the Biofield Energy Healing based Test formulation and DMEM have the capacity to decrease the skin melanin level, and it might be expected that Biofield Energy Treatment inhibits the tyrosinase enzymes activity, which is responsible for melanin synthesis [35]. Besides, the presence of important minerals in the test formulation containing Centella asiatica extract and THC, and all are reported to have significant effects against skin infection, inflammatory dermatoses, with strong antioxidant action [36, 37]. Overall, the Biofield Energy Healing based test formulation and DMEM would be useful to decline the process of melanogenesis and could be helpful for various skin-related disorders and pigmentation problems.

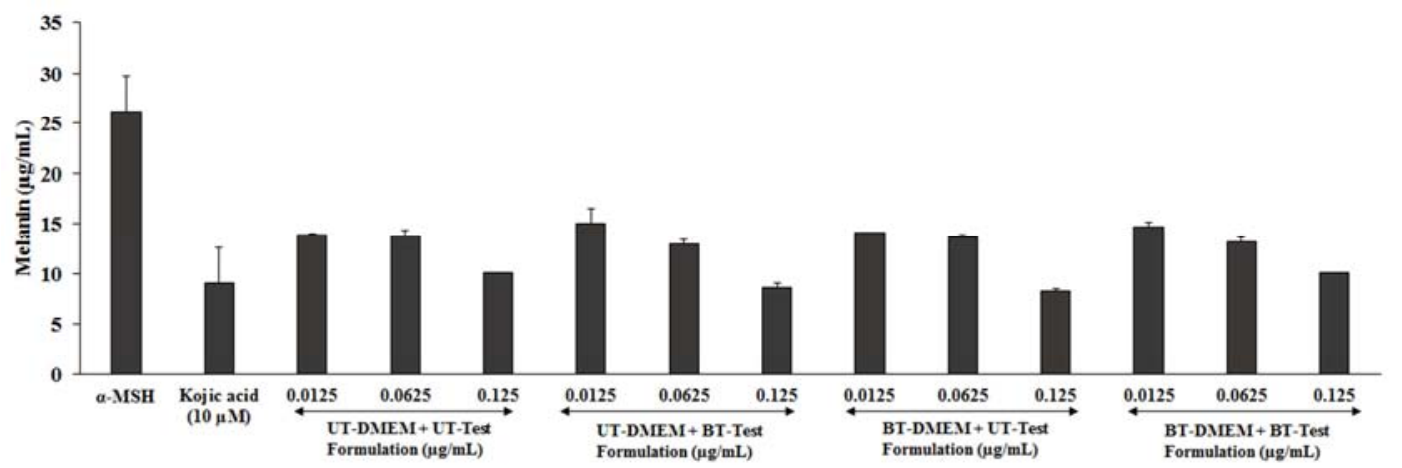

Figure 6. Inhibitory effect of the Biofield Energy Treated Test formulation on melanogenesis (skin whitening potential) in B16-F10 cell line. $\alpha$-MSH: Alpha melanocyte stimulating hormone; UT: Untreated; BT: Biofield Treated. 


\subsection{Anti-Wrinkling Effects of Test Formulation on $U V-B$ Induced Photoaging}

The anti-wrinkling potential of the Biofield Treated Test formulation with respect to the cell viability from UV-B rays is presented in Figure 7. HFF-1 cells are used to study the impact of the Biofield Energy Healing based Test formulation in cell viability potential as stress was induced by UV-B. HFF-1 cells were subjected to the lethal dose of UV-B irradiation $\left(200 \mathrm{~mJ} / \mathrm{cm}^{2}\right)$ and percentage cell viability due to UV-B irradiation was recognized. The HFF-1 cells while exposure of UV-B showed high degree of cell death with approximately $25.21 \%$ of cell viability. The cell viability in vehicle control group was found as $27.78 \%$ due to UV-B irradiation $\left(200 \mathrm{~mJ} / \mathrm{cm}^{2}\right)$. However, ascorbic acid (50 $\mu \mathrm{M})$ showed a significant increase in the cell viability $43.17 \%$. The experimental groups showed that all the groups in tested concentrations reported improved cell viability. Among the tested groups, at $2.5 \mu \mathrm{g} / \mathrm{mL}$ concentration UTDMEM + BT-Test formulation and BT-DMEM + BT-Test formulation groups showed increased cell viability by $8.21 \%$ and $11.56 \%$, respectively compared with the UT-DMEM + UT-Test formulation group. Similarly, at a concentration of
$1.25 \mu \mathrm{g} / \mathrm{mL}$ UT-DMEM + BT-Test formulation and BTDMEM + BT-Test formulation group showed increase cell viability by $14.54 \%$ and $11.32 \%$, respectively compared with the UT-DMEM + UT-Test formulation group. Besides, a slight increase was also found in UT-DMEM + BT-Test formulation group at $0.625 \mu \mathrm{g} / \mathrm{mL}$ by $2.97 \%$ compared with the UT-DMEM + UT-Test formulation group. In addition, all the experimental groups have shown significant alterations with respect to the untreated group. The results showed improved cell viability after the Biofield Energy Treated Test formulation, however UV-B results in loss in cell viability and cause skin damage. It was reported that most of the skin related diseases are somehow due to the exposure of UV-B radiation like skin disorders, stress, free radical generation, etc. This results in downregulation of the human skin fibroblasts via various inflammatory responses, DNA damage, wrinkles and skin-ageing [38]. Therefore, the Biofield Energy Healing based Test formulation and DMEM would be a better skin treatment strategy for skin protection and cell viability against UV-B radiations and can be effectively used as anti-wrinkling action.

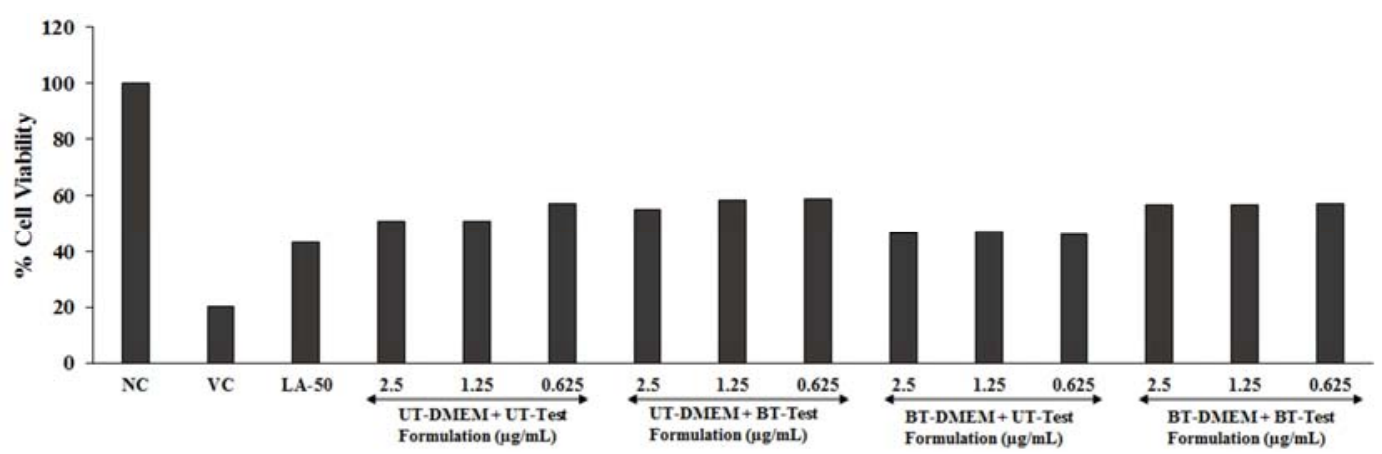

Figure 7. Anti-wrinkling potential of Biofield Energy Treated Test formulation against UV-B induced stress in HFF-1 cell lines. NC: Normal control; VC: Vehicle control; LA-50: L-Ascorbic acid at $50 \mu \mathrm{M}$ concentration. UT: Untreated; BT: Biofield Treated.

\subsection{Wound-Healing Scratch Assay}

The Biofield Energy Treated test formulation was evaluated for wound healing using scratch assay in HFF-1 and HaCaT cells. The representative pictures of HFF-1 and $\mathrm{HaCaT}$ cells after exposure of test formulation results in cellular migration, which were monitored and are presented in Figure 8. Biofield Energy Treated test formulation showed significant cellular migration, and it suggest the cell-to-cell and cell-to-matrix interactions during the wound healing process [39]. Besides, the results were analyzed at 16 hours in various groups such as positive control, EGF group, vehicle control, and Biofield Treated test formulation combinations with DMEM. It found that at 5 and $10 \mu \mathrm{g} / \mathrm{mL}$ UT-DMEM + BT-Test formulation group showed significant healing effects and cell migration compared with other experimental groups in HFF-1 cells. However, in HaCaT cell lines, scratch assay showed significant healing rate in BT-DMEM + BT-Test formulation group at $10 \mu \mathrm{g} / \mathrm{mL}$ compared with various tested group. Overall, the scratched monolayer in both cells lines showed significant migration after treatment with the Biofield Energy Treated Test formulation/DMEM compared with untreated Test formulation/DMEM group. In addition, the experimental data suggests that $2 \%$ to $10.5 \%$ increases in percentage cell coverage area in HFF-1 cells with respect to concentration of untreated test formulation, while $1.4 \%$ to $8.3 \%$ increases in cellular area covered in $\mathrm{HaCaT}$ cells in the Biofield Energy Treated test formulation compared with the untreated group. The results after treatment of test formulation in wound healing scratch assay in EGF group are shown in Figure 8 (b), normal control group in Figure 8 (a). Similarly, in UT-DMEM + BT-Test formulation and BT-DMEM + UT-Test formulation experimental group showed significant rate of cellular migration rate along with wound closure as shown in Figure 8 (d, e, f), compared with the UT-Test formulation + UT-DMEM group (Figure $8 \mathrm{c}$ ). Thus, results concluded that the Biofield Energy Healing (The Trivedi Effect ${ }^{\circledR}$ ) based herbomineral formulation and DMEM has the capacity to improve cellular migration, which results in improved wound healing. 
HFF-1 Cells

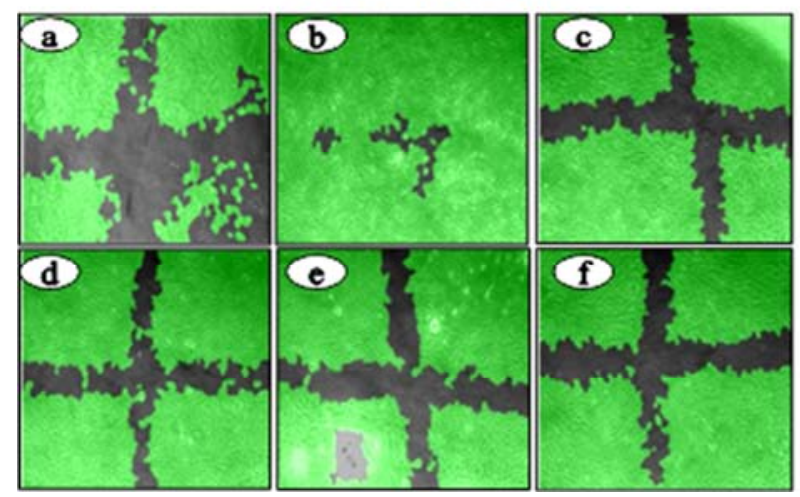

HaCaT Cells

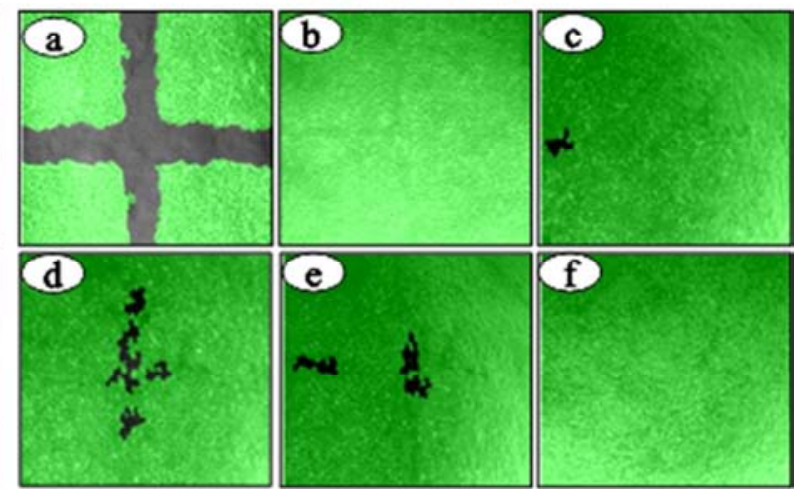

Figure 8. Representative images of HFF-1 and HaCaT cell migration cells after induction (i.e. at 0 hours) of a scratch the presence of EGF and Biofield Energy Treated Test formulation. Pictures are taken at 50 times magnification. Images represents HFF-1 and HaCaT cells migration in presence of (a) baseline control media, (b) EGF, (c) UT-DMEM + UT-Test formulation, (d) UT-DMEM + BT-Test formulation, (e) BT-DMEM + UT-Test formulation, and (f) $B T-D M E M+B T$-Test formulation.

\section{Conclusions}

The experimental data exhibited significantly improved cell viability evaluated using MTT assay. The data showed more than $70 \%$ cells were viable in all the tested concentrations such as HFF-1 (1.25 to $10 \mu \mathrm{g} / \mathrm{mL})$, HaCaT (0.625 to $5 \mu \mathrm{g} / \mathrm{mL}$ ), and B16-F10 (10 to $40 \mu \mathrm{g} / \mathrm{mL}$ ). BrdU assay indicated $43.63 \%$ and $10.97 \%$ increase in the cellular proliferation in the BT-DMEM + UT-Test formulation and BT-DMEM + BT-Test formulation groups, respectively compared to the UT-DMEM + UT-Test formulation group. The collagen level was increased by $23.56 \%$ and $13.36 \%$ in the UT-DMEM + BT-Test formulation and BT-DMEM + UT-Test formulation group respectively, at the concentration of $1.25 \mu \mathrm{g} / \mathrm{mL}$ with respect to the UT-DMEM + UT-Test formulation group. The level of elastin was significantly increased by $8.34 \%$ in the BT-DMEM + BT-Test formulation at $2.5 \mu \mathrm{g} / \mathrm{mL}$ compared to the UT-DMEM + UT-Test formulation group. Hyaluronic acid was significantly increased by $2.60 \%$ in the BT-DMEM + UT-Test formulation group at $0.625 \mu \mathrm{g} / \mathrm{mL}$ compared to the UT-DMEM + UTTest formulation group. Melanin level was reduced by $14.22 \%$ and $17.61 \%$ in the UT-DMEM + BT-Test formulation and BT-DMEM + UT-Test formulation groups, respectively compared with the UT-DMEM + UT-Test formulation group at $0.125 \mu \mathrm{g} / \mathrm{mL}$. Anti-wrinkling effects with respect to UV-B showed $4.17 \%$ and $5.88 \%$ at $2.5 \mu \mathrm{g} / \mathrm{mL}$ in the UT-DMEM + BT-Test formulation and BT-DMEM + BT-Test formulation group respectively, compared to the UTDMEM + UT-Test formulation group. The wound healing scratch assay indicated a significant migration of fibroblast and keratinocytes cells with increased covered area up to $10.50 \%$ and $8.30 \%$ in HFF-1 and $\mathrm{HaCaT}$ cells respectively after treatment with the Biofield Energy based herbomineral test formulation. Altogether, the Biofield Energy Treated Test formulation (The Trivedi Effect ${ }^{\circledR}$-Consciousness Energy Healing Treatment) and DMEM have shown significant skin protection action, which suggests its use against wrinkling, aging, skin whitening, and wound healing. Therefore, test formulation could be suitable for prevention and improvement of various skin related disorders as a novel herbal cosmetics.

Overall, the Biofield Energy Treated test formulation can be used as a Complementary and Alternative Medicine (CAM) with a safe therapeutic index for various skin irregularities that are typically symptoms of a skin disorders such as Eczema, diaper rash, chickenpox, measles, warts, acne, hives, wrinkles, ringworm, Rosacea, psoriasis, seborrheic dermatitis, skin cancer, rashes from bacterial or fungal infections, rashes from allergic reactions, raised bumps that are red or white, cracked skin, discolored patches of skin, fleshy bumps, warts, or other skin growths, changes in mole color or size, a loss of skin pigment, scaly or rough skin, peeling skin, ulcers, open sores or lesions, dry, excessive flushing. Further, the Biofield Energy Healing based herbomineral test formulation can also be used in the prevention of temporary and permanent skin disorders, antiaging, improved overall health, and quality of life.

\section{Abbreviations}

THC: Tetrahydrocurcumin; DMEM: Dulbecco's Modified Eagle's Medium; ECM: Extracellular matrix; EGF: Epidermal growth factor; $\alpha$-MSH: $\alpha$-Melanocyte-stimulating hormone; HA: Hyaluronic acid; HFF-1: Human foreskin fibroblast cell line; B16-F10: Mouse melanoma cell line; HaCaT: Human keratinocytes cells; NCCAM: National Center for Complementary and Alternative Medicine.

\section{Acknowledgement}

Authors are grateful to Dabur Research Foundation, Trivedi Global, Inc., Trivedi Science, Trivedi Testimonials, and Trivedi Master Wellness for their support throughout the work. 


\section{References}

[1] Tabassum N, Hamdani M (2014) Plants used to treat skin diseases. Pharmacogn Rev 8: 52-60.

[2] Goyal RK (2005) Investigation of cellular and molecular mechanisms for anti-diabetic drugs with special reference to Unani and Ayurvedic herbal medicines. In: traditional system of medicine, Abdin, M. Z. and Y. P. Abrol (Eds.). Narosa Publishing House, New Delhi.

[3] WHO (1993) Research Guideline for Evaluating the Safety and Efficacy of Herbal Medicines. World Health Organization, Manila, Philippines.

[4] Gao XH, Zhang L, Wei H, Chen HD (2008) Efficacy and safety of innovative cosmeceuticals. Clin Dermatol 26: 367-74.

[5] Fabricant DS, Farnsworth NR (2001) The value of plants used in traditional medicine for drug discovery. Environ Health Perspect 109: 69-75.

[6] Park K (2015) Role of micronutrients in skin health and function. Biomol Ther (Seoul) 23: 207-217.

[7] Hashim P (2011) Centella asiatica in food and beverage applications and its potential antioxidant and neuroprotective effect. Int Food Res J 18: 1215-1222.

[8] Boyera N, Galey I, Bernard BA (1998) Effect of vitamin C and its derivatives on collagen synthesis and cross-linking by normal human fibroblasts. Int J Cosmet Sci 20: 151-158.

[9] Gupta SC, Patchva S, Koh W, Aggarwal BB (2012) Discovery of curcumin, a component of golden spice, and its miraculous biological activities. Clin Exp Pharmacol Physiol 39: 283-299.

[10] Majeed M, Badmaev V, Uma S, Rajenderan JR (1995) Curcuminoids: Antioxidant Phytonutrients, Nutreiscience publishers New Jersey 1-24.

[11] Sugiyama Y, Kawakishi S, Osawa T (1996) Involvement of the $\beta$-diketone moiety in the antioxidant mechanism of tetrahydrocurcuminoids. Biochem Pharmacol 52: 519-525.

[12] Bylka W, Znajdek-Awiżeń P, Studzińska-Sroka E, Brzezińska M (2013) Centella asiatica in cosmetology. Postepy Dermatol Alergol 30: 46-49.

[13] Rubik B, Muehsam D, Hammerschlag R, Jain S (2015) Biofield science and healing: history, terminology, and concepts. Glob Adv Health Med 4: 8-14.

[14] Barnes PM, Bloom B, Nahin RL (2008) Complementary and alternative medicine use among adults and children: United States, 2007. Natl Health Stat Report 12: 1-23.

[15] Trivedi MK, Patil S, Shettigar H, Gangwar M, Jana S (2015) Antimicrobial sensitivity pattern of Pseudomonas fluorescens after biofield treatment. J Infect Dis Ther 3: 222.

[16] Trivedi MK, Patil S, Shettigar H, Bairwa K, Jana S (2015) Phenotypic and biotypic characterization of Klebsiella oxytoca: An impact of biofield treatment. J Microb Biochem Technol 7: 203-206.

[17] Trivedi MK, Patil S, Shettigar H, Gangwar M, Jana S (2015) An effect of biofield treatment on multidrug-resistant Burkholderia cepacia: A multihost pathogen. J Trop Dis 3: 167.
[18] Patil SA, Nayak GB, Barve SS, Tembe RP, Khan RR (2012) Impact of biofield treatment on growth and anatomical characteristics of Pogostemon cablin (Benth.). Biotechnology 11: 154-162.

[19] Nayak G, Altekar N (2015) Effect of biofield treatment on plant growth and adaptation. J Environ Health Sci 1: 1-9.

[20] Trivedi MK, Branton A, Trivedi D, Nayak G, Mondal SC, Jana S (2015) Effect of biofield treated energized water on the growth and health status in chicken (Gallus gallus domesticus). Poult Fish Wildl Sci 3: 140.

[21] Trivedi MK, Tallapragada RM (2008) A transcendental to changing metal powder characteristics. Met Powder Rep 63: $22-28,31$.

[22] Trivedi MK, Nayak G, Patil S, Tallapragada RM, Latiyal O (2015) Studies of the atomic and crystalline characteristics of ceramic oxide nano powders after bio field treatment. Ind Eng Manage 4: 161.

[23] Trivedi MK, Nayak G, Patil S, Tallapragada RM, Latiyal O, Jana S (2015) Effect of Biofield energy treatment on physical and structural properties of calcium carbide and praseodymium oxide. International Journal of Materials Science and Applications 4: 390-395.

[24] Trivedi MK, Tallapragada RM, Branton A, Trivedi D, Nayak G, Latiyal O, Jana S (2015) Characterization of physical, thermal and structural properties of chromium (VI) oxide powder: impact of biofield treatment. J Powder Metall Min 4: 128.

[25] Plumb JA (2004) Cell sensitivity assays: the MTT assay. Methods Mol Med 88:165-169.

[26] Hahn MS, Kobler JB, Starcher BC, Zeitels SM, Langer R (2006) Quantitative and comparative studies of the vocal fold extracellular matrix. I: Elastic fibers and hyaluronic acid. Ann Otol Rhinol Laryngol 115: 156-164.

[27] Zhang L, Yoshida T, Kuroiwa Y (1992) Stimulation of melanin synthesis of B16-F10 mouse melanoma cells by bufalin. Life Sci 51:17-24.

[28] Shoulders MD, Raines RT (2009) Collagen structure and stability. Annual review of biochemistry 78: 929-958.

[29] Fronza M, Heinzmann B, Hamburger M, Laufer S, Merfort I (2009) Determination of the wound healing effect of Calendula extracts using the scratch assay with 3T3 fibroblasts. J Ethnopharmacol 126: 463-467.

[30] Kadler KE, Holmes DF, Trotter JA, Chapman JA (1996) Collagen fibril formation. Biochemical Journal 316: 1-11.

[31] Shoulders MD, Raines RT (2009) Collagen structure and stability. Annual review of biochemistry 78: 929-958.

[32] Frantz C, Stewart KM, Weaver VM (2010) The extracellular matrix at a glance. J Cell Sci 123: 4195-4200.

[33] Weindl G, Schaller M, Schäfer-Korting M, Korting HC (2004) Hyaluronic acid in the treatment and prevention of skin diseases: molecular biological, pharmaceutical and clinical aspects. Skin Pharmacol Physiol 17: 207-213.

[34] Alaluf S, Atkins D, Barrett K, Blount M, Carter N, et al. (2002) The impact of epidermal melanin on objective measurements of human skin colour. Pigment Cell Res. 15: 119-126. 
[35] Busca R, Ballotti R (2000) Cyclic AMP a key messenger in the regulation of skin pigmentation. Pigment Cell Res 13: 6069.

[36] Bylka W, Znajdek-Awiżeń P, Studzińska-Sroka E, Brzezińska M (2013) Centella asiatica in cosmetology. Postepy Dermatol Alergol 30: 46-49.

[37] Prasad S, Tyagi AK, Aggarwal BB (2014) Recent developments in delivery, bioavailability, absorption and metabolism of curcumin: the golden pigment from golden spice. Cancer Res Treat 46: 2-18.
[38] Ho JN, Lee YH, Lee YD, Jun WJ, Kim HK, Hong BS, Shin DH, Cho HY (2005) Inhibitory effect of Aucubin isolated from Eucommia ulmoides against UVB induced matrix metalloproteinase-1 production in human skin fibroblasts. Biosci Biotechnol Biochem 69: 2227-2231.

[39] Liang CC, Park AY, Guan JL (2007) In vitro scratch assay: A convenient and inexpensive method for analysis of cell migration in vitro. Nat Protoc 2: 329-333. 